\title{
Iodine Fortification Study of Some Common African Vegetables
}

\author{
Chigozie John Onyinye Anarado, Charity Ebere Anarado* ${ }^{(0)}$, Richard Ifeanyi Areh, \\ Nonyelum Ifoh, Elijah Okechukwu Eze, Ebuka Ikeakor
}

Department of Pure and Industrial Chemistry, Nnamdi Azikiwe University, Awka, Nigeria

Email: *ce.anarado@unizik.edu.ng

How to cite this paper: Anarado, C.J.O., Anarado, C.E., Areh, R.I., Ifoh, N., Eze, E.O. and Ikeakor, E. (2019) Iodine Fortification Study of Some Common African Vegetables. Journal of Agricultural Chemistry and Environment, 8, 172-183.

https://doi.org/10.4236/jacen.2019.83014

Received: July 9, 2019

Accepted: August 19, 2019

Published: August 22, 2019

Copyright $\odot 2019$ by author(s) and Scientific Research Publishing Inc. This work is licensed under the Creative Commons Attribution International License (CC BY 4.0).

http://creativecommons.org/licenses/by/4.0/

\begin{abstract}
Iodine Deficiency Diseases (IDDs) occupy important positions in the health problems of developing countries. Salt Iodisation has been the common approach to solving these problems. However, apart from the problems of lack of compliance by salt manufacturers, and inculturation of the consumers, health conditions aggravated by high salt intake by humans have become increasingly relevant. These problems can be eliminated if the commonly produced and consumed plants are fortified with Iodine. The prospects are in the inclusion of Iodine-containing compounds in the inorganic fertilizers used by farmers. In this study, Potassium Iodide and Potassium Iodate were used as inoculants. Five different concentrations- $0.1 \mathrm{M}, 0.2 \mathrm{M}, 0.3 \mathrm{M}, 0.4 \mathrm{M}$, and 0.5 $\mathrm{M}$ of Potassium Iodide and Potassium Iodate solutions were used to inoculate the soils on which the following edible African plants were planted: Murraya koenigii; Ocimum gratissimum; Cucurbita pepo; Solanum nigrum; Amaranthus hybridus and Abelmoschus esclentus, Corchorous olitoruis, Solanum lycopersicum, Zingiber officinale, Telfairia occidentalis, Talinium triangulare, Solanum melongena. Controls were also planted. After 14 days, alkaline dry ash method was used to determine the Iodine concentrations in the plants. The results showed that Murraya koenigii showed the highest absorption of Iodine $6.90 \mathrm{mg} / \mathrm{kg}$ at $0.3 \mathrm{M}$ using KI, followed by Amaranthus hybridus 6.40 $\mathrm{mg} / \mathrm{kg}$ at $0.1 \mathrm{M}$. Solanum nigrum, Ocimum gratissimum and Zingiber officinale also showed good absorption. Other plants except Murraya koenigii, Ocimum gratissimum, Solanum nigrum and Zingiber officinale showed very low tolerance to KI absorption. The result also showed that Telfairia occidentalis showed the highest absorption of iodine $8.20 \mathrm{mg} / \mathrm{kg}$ at $0.2 \mathrm{M}$ of $\mathrm{KIO}_{3}$ followed by Cucurbita pepo $6.40 \mathrm{mg} / \mathrm{kg}$ at also $0.2 \mathrm{M}$ of $\mathrm{KIO}_{3 .}$. Murraya koenigii, Ocimum gratissimum, Solanum nigrum, Zingiber officinale also showed good absorption of $\mathrm{KIO}_{3}$. Some of the plants were not able to tolerate the absorption at higher concentration for both $\mathrm{KI}$ and $\mathrm{KIO}_{3}$. All the plants
\end{abstract}


were poisoned at concentration of $0.5 \mathrm{M}$ for both $\mathrm{Ki}$ and $\mathrm{KIO}_{3}$. Murraya koenigii, Ocimum gratissimum, Solanum nigrum, Zingiber officinale can be used in iodine biofortification using $\mathrm{KI}$ and $\mathrm{KIO}_{3}$ at concentration $<0.5 \mathrm{M}$. The overall result may be very significant, when it is considered that Iodine is a micronutrient, with a daily intake requirement of $100-150 \mu \mathrm{g} / \mathrm{kg}$. It can be seen that there is hope in achieving this kind of biofortification.

\section{Keywords}

Iodine Deficiency Disease (IDD), Biofortification, Iodisation, Potassium Iodide, Potassium Iodate: Murraya koenigii, Ocimum gratissimum, Cucurbita pepo, Solanum nigrum, Amaranthus hybridus, Abelmoschus esclentus, Corchorous olitorius, Solanum lycopersicum, Zingiber officinale, Telfairia occidentalis, Talinium triangulare, Solanum melongena

\section{Introduction}

Agriculture can inevitably play a big role in improving nutrition and health in developing countries. However, advancement in agriculture has often concentrated on increasing production to avert food insecurity, at the expense of improving the nutrient content of the food crop. As such, many farming systems currently cannot produce enough micronutrients to meet human requirements in a sustainable way [1]. Deficiencies in vitamins and minerals in our diets create major public health problems, mental as well as physical, especially in developing countries. Conventional responses (diet diversification, supplementation, fortification of manufactured foods) have had limited impacts [2]. Iodine is a trace element that is fundamental for human health: Iodine deficiency (ID) is the result of insufficient dietary iodine intake and in humans results in multiple adverse effects due to inadequate synthesis of thyroid hormone (whose classic sign is goiter, the enlargement of the thyroid gland) that has multiple functions such as enhancing protein synthesis, regulating energy transfer, accelerating growth and development, and maintaining the structure of central nervous system. The resulted physiological disorders and biological function abnormalities are called iodine deficiency disease (IDD). Despite myriad improvements to global food production systems in the context of human nutrition, about two billion people worldwide are affected by IDD, with those in south Asia and sub-Saharan Africa particularly affected. Iodine deficiency has many adverse effects on growth and development. Fruits and vegetables are usually poor sources of iodine; however, plants can accumulate iodine if it is either present or exogenously administered to the soil [3]-[9]. At least one billion people are at risk of IDD. Iodine deficiency, therefore, constitutes one of the most common preventable causes of mental deficiency in the world today. Most of the affected populations live in mountainous areas in preindustrialized countries, but 50 to 100 million people are still at risk in Europe [10] [11]. Salt iodization programs 
have alleviated the scourge significantly in some regions, however, the use of iodized salt in food processing is still extensively inadequate and the volatilization of iodine during food storage, transport or cooking is high. Furthermore, the policies adopted by many countries are aimed at reducing salt intake in order to prevent hypertension and cardiovascular diseases and so multipronged approach will be needed to ultimately defeat this pervasive disease [7] [12] [13]. Iodine is present in soils as iodide, iodate and organic iodine compounds. Little iodine is present in the soil solution and most soil iodine is associated with organic matter, clays and oxides of $\mathrm{Fe}$ and $\mathrm{Al}$ [14]. In some areas surface soil becomes progressively poorer in iodine through accelerated deforestation, soil erosion and leaching processes [15]. The bio fortification of crops with iodine has therefore been proposed as a strategy for improving human nutrition. Producing iodine enriched crops through bio fortification could be an effective way to reduce the deficiency effects [8] [16]. Biofortification is the process of adding nutritional value to the crop. It refers to nutrient enrichment of crops to address the negative economic and health consequences of vitamin and mineral deficiencies in humans [17]. Biofortification, the increase of micronutrients in the edible parts of the plants, can be achieved by either mineral fertilization or plant breeding [18] [19]. Biofortification, the process of enriching staple foods with essential micronutrients, is one of the key alternatives recommended to increase iodine availability and consumption using the best traditional breeding practices and modern biotechnology. This approach has multiple advantages. First, it capitalizes on the regular daily intake of a consistent and large amount of food staples by all family members. Because staple foods predominate in the diets of the poor, this strategy implicitly targets low-income households. Second, after the one-time investment to develop seeds that fortify themselves, recurrent costs are low, and germplasm can be shared internationally. This multiplier aspect of plant breeding across time and distance makes it cost-effective. Third, once in place, the biofortified crop system is highly sustainable. Nutritionally improved varieties will continue to be grown and consumed year after year, even if government attention and international funding for micronutrient issues fade. Fourth, biofortification provides a feasible means of reaching undernourished populations in relatively remote rural areas, delivering naturally fortified foods to people with limited access to commercially marketed fortified foods that are more readily available in urban areas [1] [20]. Recent studies demonstrated that leafy vegetables such as spinach or lettuce can store iodine in their edible tissues, making them good candidates for iodine biofortification programs [16]. Biofortification is a feasible and cost-effective means of delivering micronutrients to populations that may have limited access to diverse diets and other micronutrient interventions [21] [22] [23]. Vegetables are fresh, edible portion of plant that are either eaten raw or in cooked form. They contain both essential and toxic elements over a wide range of concentrations [24]. Murraya koenigii is a culinary important plant of Indian origin, and also been a 
component of many formulations used in the Ayurvedic system of medicine since many centuries. A scrutiny of literature reveals some notable pharmacological activities of the plant. Carbazole alkaloids which are abundantly present in the leaves, fruits, roots and bark of this plant, have been reported for their antidiabetic, anticancer, antibacterial, anti-nociceptive and antioxidant activities. Besides these activities, the plant is described to have a wide array of therapeutic activities [25]. Ocimum gratissimum is also used in the management of baby's cord and in the treatment of fungal infections, fever and cold [26]. Cucurbita pepo seeds and seed extracts represent a complex mixture of substances, and their effects may not be attributed to just a few ingredients. It is significant for the treatment of BHP, a condition that commonly affects men 50 years and older and involves enlargement of the prostate gland [27]. Solanum nigrum Linn. (Solanaceae) commonly known as "Black nightshade" that have been extensively used in traditional medicine in India and other parts of world to cure liver disorders, chronic skin ailments (psoriasis and ringworm), inflammatory conditions, painful periods, fevers, diarrhea, eye diseases, hydrophobia, etc. [28]. Amaranthus hybridus leaves combined with condiments are used to prepare soup [29]. Abelmoschus esculentus has found medical application as a plasma replacement or blood volume expander and also useful in genitor-urinary disorders, spermatorrhoea and chronic dysentery [30]. ute (Corchorus olitorius L.) is an indigenous leafy vegetable which leaves are very rich in amino acid and essential minerals and they form part of the meals of people of Asia, Middle East and parts of Africa [31]. Tomato (Solanum lycopersicum L.) is an important vegetable crop. It is a rich source of vitamins, minerals, and fiber, and a dietary source of antioxidants [32]. Zingiber officinale commonly known as ginger, is a spice consumed worldwide for culinary and medicinal purposes. The plant has a number of chemicals responsible for its medicinal properties, such as antiarthritis, antiinflammatory, antidiabetic, antibacterial, antifungal, anticancer, etc. [33]. The fluted pumpkin (Telfairia occidentalis Hook f.), a member of the Cucurbitaceae, is a strong climber and short-termperennial [34]. It is widely cultivated for its palatable and nutritious leaves which are used mainly as vegetable. The seeds are also nutritious and rich in an oil which may be used for cooking and soap manufacture [35]. Talinum triangulare (water leaf) is an herbaceous perennial; caules cent and glabrous plant widely grow in tropical regions as a leaf vegetable [36]. Solanum melongena L.) belongs to the Leptostemonum Clade (the "spiny" solanums) of the species-rich genus Solanum (Solanaceae). Unlike most of the genus, the eggplant and its relatives are from the Old World; most eggplant wild relatives are from Africa [37]. Eggplants, and the closely related Solanum species belonging to the subgenus Leptostemonum, are some of the most important vegetable crops in Asia, the Middle and Near East, Southern Europe, and Africa and are some of the key materials of various cuisines in these countries [38]. Various have reported incidence of Iodine Deficiency Disorders, in India, Vietnam, Iran, Bangladesh, Nepal, even in iodine-replete environment 
like Eastern Europe, North America and endemic in the mountain regions of Armenia [38]-[49]. Incidences of IDDs have been reported in some Sub Saharan African countries by Saha et al., 2019 [50]. Many other African countries like in Sudan, an Emergency Food Security and Nutrition Assessment Survey (EFSNA) revealed the prevalence of IDD among adult women and children, More than 2 out of 10 school age children have goiter [51]. Some other researchers also reported Iodine deficiency being highly prevalent among rural South Sudan communities and a likely cause for goiters. Rural poor women are highly vulnerable [52]. Prevalent Endemic goiter was also reported by A cross-sectional survey conducted in Shebe Senbo District, Jimma Zone, Southwest Ethiopia and Ada district, Oromia region, Ethiopia [53] [54]. A systematic review of data from 2005 to 2015 conducted in 2017 also revealed prevalence of ID ranged from 9\% to $18 \%$ in Ethiopia, Nigeria and South Africa [55]. Ogbera and Kuku, 2011 reported endemic goiter in some African countries like New Guinea, Cameroun, Northern Zaire, Central Africa Republic, Uganda, and Rwanda, and occurrence of heart failure in $42 \%$ of subjects with thyrotoxicosis in Lagos Nigeria [56]. Mshelia et al., 2016 also reported the presence of iodine deficiency in Maiduguri, north-eastern Nigeria, especially in females [57]. Ogbera et al., 2007 reported Thyroid disorders as significant causes of cardiovascular morbidity Nigeria [58]. Salami et al., 2016 reported high prevalent thyroid diseases in a tertiary hospital in Nigeria especially in female [59]. From the above literature, it can be seen that despite increase in daily iodine intake through salt iodisation, endemic and prevalence IDDs are still present especially in Africa. And also considering health effect of increased consumption of Sodium chloride as potential cause of hypertension and cardiovascular diseases [60], importance of iodine fortification of common vegetables cannot be overemphasized and therefore this work.

\section{Materials Used}

PD303 UV Spectrophotometer, CF-30 Teco Centrifuge, Ohaus EX224 analytical weighing balance, Thermolyne F47925-80 benchtop Muffle furnace, nickel crucible, air-tight jar, measuring cylinder, beakers, $\mathrm{KIO}_{3}, \mathrm{KI}, \mathrm{KNO}_{3}, \mathrm{NaOH}$, Ceric ammonium sulphate, sodium arsenite, seeds of Murraya koenigii, Ocimum gratissimum, Cucurbita pepo, Solanum nigrum, Amaranthus hybridus, Abelmoschus esculentus, Corchorous olitoruis, Solanum lycopersicum, Zingiber officinale, Telfairia occidentalis, Talinium triangulare, Solanum melongena, distilled water.

\section{Methods}

The seeds of Murraya koenigii, Ocimum gratissimum, Cucurbita pepo, Solanum nigrum, Amaranthus hybridus, Abelmoschus esculentus, Corchorous olitoruis, Solanum lycopersicum, Zingiber officinale, Telfairia occidentalis, Talinium triangulare, Solanum melongena were bought from Eke Awka market in Awka, the State Capital of Anambra State, Nigeria. The seeds were planted in nurseries and the seedlings transplanted to one hundred and thirty two (132) beds. Each plant was planted in eleven beds, $20 \mathrm{ml}$ of each of $0.1 \mathrm{M}, 0.2 \mathrm{M}, 0.3 \mathrm{M}, 0.4 \mathrm{M}$ and 0.5 
$\mathrm{M}$ of Potassium iodide $0.1 \mathrm{M}, 0.2 \mathrm{M}, 0.3 \mathrm{M}, 0.4 \mathrm{M}$ and $0.5 \mathrm{M}$ of potassium iodate was added to each of the plants. One each of the plants was left uninoculated (control). Dry Alkaline Ash Method of analysis, was used after 14 days. This was done by adding $0.5 \mathrm{~g}$ of each of the samples into a nickel crucible. $1 \mathrm{ml}$ of a mixture $0.5 \mathrm{M}$ sodium hydroxide and $0.1 \mathrm{M}$ potassium nitrate was added to the samples, mixed and allowed to dry. The containers were covered, placed in a muffle furnace, heated to $250^{\circ} \mathrm{C}$, held, for 15 minutes, and heated further to $480^{\circ} \mathrm{C}$, held for 15 minutes, and finally brought to $580^{\circ} \mathrm{C}$. The temperature was maintained for three hours, allowed to cool to room temperature. The resultant ashed was extracted with three successive $2 \mathrm{ml}$ portions of a $1.0 \mathrm{mM} \mathrm{NaOH}$, made up double-distilled water. The solution was centrifuged at $2500 \mathrm{~g}$ for 20 minutes using polypropylene centrifuge tubes and the supernatant solution collected for iodine determination. Iml of the sample solution was added to a cuvette at $35^{\circ} \mathrm{C}$ and $1 \mathrm{ml}$ sodium arsenite, and $1 \mathrm{ml}$ of ceric ammonium sulphate. A standard curve containing 0.5 to $10 \mathrm{ppm}$ iodine was used. The intensity of the developed colour was measured at $420 \mathrm{~nm}$. The iodine concentration in the samples was calculated from the standard curve. Concentrations of the control were deducted from the concentrations of the inoculated.

\section{Results}

See Table 1 and Table 2.

Table 1. Result of absorbed $\mathrm{I}_{2}$ for KI by the plants (mg/kg).

\begin{tabular}{cccccc}
\hline Plant & $\begin{array}{c}\text { Absorbed } \\
\mathrm{I}_{2} \text { for } \\
0.1 \mathrm{M} \mathrm{KI}\end{array}$ & $\begin{array}{c}\text { Absorbed } \\
\mathrm{I}_{2} \text { for } \\
0.2 \mathrm{M} \mathrm{KI}\end{array}$ & $\begin{array}{c}\text { Absorbed } \\
\mathrm{I}_{2} \text { for } \\
0.3 \mathrm{M} \mathrm{KI}\end{array}$ & $\begin{array}{c}\text { Absorbed } \\
\mathrm{I}_{2} \text { for }\end{array}$ & $\begin{array}{c}\text { Absorbed } \\
\mathrm{I}_{2} \text { for }\end{array}$ \\
$\begin{array}{ccccc}\text { Murraya koenigii } \\
\text { Ocimum gratissimum }\end{array}$ & 6.50 & 2.33 & 6.90 & Died & Died \\
Cucurbita pepo & 2.30 & 2.20 & 2.35 & 2.31 & Died \\
Solanum nigrum, & 6.80 & 2.50 & Died & Died & Died \\
Amaranthus hybridus & 6.40 & Died & Died & Died & Died \\
Abelmoschus esculentus & 2.20 & Died & Died & Died & Died \\
Corchorous olitoruis & Died & Died & Died & Died & Died \\
Solanum lycopersicum & Died & Died & Died & Died & Died \\
Zingiber officinale & 1.60 & 1.62 & 1.62 & 2.40 & Died \\
Telfairia occidentalis & Died & Died & Died & Died & Died \\
Talinium triangulare & Died & Died & Died & Died & Died \\
Solanum melongena & Died & Died & Died & Died & Died \\
\hline
\end{tabular}


Table 2. Result of absorbed $\mathrm{I}_{2}$ for $\mathrm{KIO}_{3}$ by the plants (mg/kg).

\begin{tabular}{|c|c|c|c|c|c|}
\hline Plant & $\begin{array}{c}\text { Absorbed } \\
\mathrm{I}_{2} \text { for } \\
0.1 \mathrm{M} \mathrm{KIO}_{3}\end{array}$ & $\begin{array}{c}\text { Absorbed } \\
\mathrm{I}_{2} \text { for } \\
0.2 \mathrm{M} \mathrm{KIO}_{3}\end{array}$ & $\begin{array}{c}\text { Absorbed } \\
\mathrm{I}_{2} \text { for } \\
0.3 \mathrm{M} \mathrm{KIO}_{3}\end{array}$ & $\begin{array}{c}\text { Absorbed } \\
\mathrm{I}_{2} \text { for } \\
0.4 \mathrm{M} \mathrm{KIO}_{3}\end{array}$ & $\begin{array}{c}\text { Absorbed } \\
\mathrm{I}_{2} \text { for } \\
0.5 \mathrm{M} \mathrm{KIO}_{3}\end{array}$ \\
\hline Murraya koenigii & 2.40 & 5.70 & 2.18 & Died & Died \\
\hline Ocimum gratissimum & 2.10 & 2.16 & 2.24 & 2.12 & Died \\
\hline Cucurbita pepo & 6.10 & 6.40 & 6.20 & 6.20 & Died \\
\hline Solanum nigrum, & 2.30 & 2.12 & 2.21 & 2.12 & Died \\
\hline Amaranthus hybridus & 2.20 & 2.50 & Died & Died & Died \\
\hline Abelmoschus esculentus & Died & Died & Died & Died & Died \\
\hline Corchorous olitoruis & Died & Died & Died & Died & Died \\
\hline Solanum lycopersicum & 1.8 & 1.33 & 1.60 & Died & Died \\
\hline Zingiber officinale & 1.30 & 1.40 & 1.60 & 1.30 & Died \\
\hline Telfairia occidentalis & 2.20 & 8.20 & Died & Died & Died \\
\hline Talinium triangulare & 6.20 & Died & Died & Died & Died \\
\hline Solanum melongena & 2.30 & Died & Died & Died & Died \\
\hline
\end{tabular}

\section{Discussions}

The result of the analysis showed that Murraya koenigii showed a very good absorption of iodine using $\mathrm{KI}$, and $\mathrm{KIO}_{3}$ at concentrations not higher than $0.3 \mathrm{M}$. With highest absorption of $6.90 \mathrm{mg} / \mathrm{kg}$ for $0.3 \mathrm{M} \mathrm{KI}$ which was the highest absorption value using KI, followed by Amaranthus hybridus $(6.40 \mathrm{mg} / \mathrm{kg})$ at 0.1 M KI and Solanum nigrum $(6.0 \mathrm{mg} / \mathrm{kg})$ at $0.1 \mathrm{M}$ and $0.2 \mathrm{M} \mathrm{KI}$. Highest absorption of Iodine using $\mathrm{KIO}_{3}$ was got with Telfairia occidentalis at $0.2 \mathrm{M}(8.20$ $\mathrm{mg} / \mathrm{kg}$ ), though the plant could not tolerate absorption of the salt beyond $0.2 \mathrm{M}$. The result also showed that Cucurbita pepo showed the very good absorption of iodine using $\mathrm{KIO}_{3} 6.10 \mathrm{mg} / \mathrm{kg}, 6.40 \mathrm{mg} / \mathrm{kg}, 6.20 \mathrm{mg} / \mathrm{kg}$ and $6.00 \mathrm{mg} / \mathrm{kg}$ at concentrations of $0.1 \mathrm{M}, 0.2 \mathrm{M}, 0.3 \mathrm{M}$ and $0.4 \mathrm{M}$ respectively. The plant showed highest tolerance for $\mathrm{KIO}_{3}$. Murraya koenigii also showed very good absorption $(2.40 \mathrm{mg} / \mathrm{kg}, 5.70 \mathrm{mg} / \mathrm{kg}$ and $2.18 \mathrm{mg} / \mathrm{kg})$ and tolerance for $\mathrm{KIO}_{3}$ at concentrations of $0.1 \mathrm{M}, 0.2 \mathrm{M}$ and $0.3 \mathrm{M}$ respectively. Solanum nigrum, Ocimum gratissimum, Solanum lycopersicum and Zingiber officinale also showed good absorption and very high tolerance for $\mathrm{KIO}_{3}$ from $0.1 \mathrm{M}$ to $0.4 \mathrm{M}$. Corchorous olitoruis, Solanum lycopersicum, Telfairia occidentalis, Talinium triangulare, Solanum melongena were poisoned by the $\mathrm{KI}$ at all concentrations. Corchorous olitoruis and Abelmoschus esculentus also showed zero tolerance to $\mathrm{KIO}_{3}$ absorption at all concentrations. Some of the plants were also not able to tolerate the absorption at higher concentration for both $\mathrm{KI}$ and $\mathrm{KIO}_{3}$. The other plants, apart from Murraya koenigii, Solanum nigrum, Zingiber officinale and Ocimum 
gratissimum were poisoned by the KI at concentrations greater than $0.3 \mathrm{M}$. Plants like Corchorous olitoruis, Amaranthus hybridus, Abelmoschus esculentus, Murraya koenigii, Solanum lycopersicum, Telfairia occidentalis, Talinium triangulare, Solanum melongena did not tolerate absorption of $\mathrm{KIO}_{3}$ at concentration > 0.3 M. All the plants were poisoned at concentration of $0.5 \mathrm{M}$ for both $\mathrm{Ki}$ and $\mathrm{KIO}_{3}$.

\section{Conclusions}

The health and well-being of a population are significantly influenced by their nutritional status. A healthy and well-balanced diet, with a variety of high-quality foods ensuring the right proportions of different types of nutrients, is important both in the prevention and in the treatment of several diseases [4].

- Some of the plants showed very good absorption of iodine, when compared with the iodine daily intake requirement, iodine fortification of these vegetables is very important in order to reduce the incidence of IDDs and also maintain a healthy diet in Africa.

- There is also need to increase phyto-availabity, and reduce phytotoxicity of iodine compounds.

\section{Conflicts of Interest}

The authors declare no conflicts of interest regarding the publication of this paper.

\section{References}

[1] Olum, S., Gellynck, X., Okello, C., Webale, D., Odongo, W., Ongeng, D. and De Steur, H. (2018) Stakeholders' Perceptions of Agronomic Iodine Biofortification: A SWOT-AHP Analysis in Northern Uganda. Nutrients, 10, 407. https://doi.org/10.3390/nu10040407

[2] Winkler, J.T. (2011) Biofortification: Improving the Nutritional Quality of Staple Crops. 100-112.

[3] Zimmermann, M.B., Jooste, P.L. and Pandav, C.S. (2008) Iodine-Deficiency Disorders. The Lancet, 372, 1251-1262. https://doi.org/10.1016/S0140-6736(08)61005-3

[4] Kiferle, C., Gonzali, S. and Holwerda, H.T. (2013) Tomato Fruits: A Good Target for Iodine Biofortification. Frontiers in Plant Science, 27, 205.

https://doi.org/10.3389/fpls.2013.00205

[5] Tonacchera, M., Dimida, A., De Servi, M., Frigeri, M., Ferrarini, E., De Marco, G., Grasso, L., Agretti, P., Piaggi, P., Aghini-Lombardi, F., Perata, P., Pinchera, A. and Vitti, P. (2013) Iodine Fortification of Vegetables Improves Human Iodine Nutrition: In Vivo Evidence for a New Model of Iodine Prophylaxis. The Journal of Clinical Endocrinology \& Metabolism, 98, E694-E697.

https://doi.org/10.1210/jc.2012-3509

[6] Weng, H.X., Hong, C.L., Xia, T.H., et al. (2013) Iodine Biofortification of Vegetable Plants-An Innovative Method for Iodine Supplementation. Chinese Science Bulletin, 58, 2066-2072. https://doi.org/10.1007/s11434-013-5709-2

[7] Yaseen, M. (2013) Iodine Biofortification through Plant Biotechnology. Journal of 
Nutrition, 29, 1431. https://doi.org/10.1016/j.nut.2013.04.009

[8] Khalid, S.M.N. (2017) Iodine Bio-Fortification of Crops for Solving Iodine Deficiency Disorder Problem in Afghanistan. Journal of Food and Nutritional Disorders, 6, 3. https://doi.org/10.4172/2324-9323.1000228

[9] Signore, A., Renna, M., D’Imperio, M., Serio, F. and Santamaria, P. (2018) Preliminary Evidences of Biofortification with Iodine of "Carota di Polignano": An Italian Carrot Landrace. Frontiers in Plant Science, 9, 170. https://doi.org/10.3389/fpls.2018.00170

[10] Zimmermann, M.B. (2008) Iodine Requirements and the Risks and Benefits of Correcting Iodine Deficiency in Populations. Journal of Trace Elements in Medicine and Biology, 22, 81-92. https://doi.org/10.1016/j.jtemb.2008.03.001

[11] Delange, F. (1994) The Disorders Induced by Iodine Deficiency. Thyroid, 4, 107-128. https://doi.org/10.1089/thy.1994.4.107

[12] Gonzali, S., Kiferle, C. and Perata, P. (2017) Iodine Biofortification of Crops: Agronomic Biofortification, Metabolic Engineering and Iodine Bioavailability. Current Opinion in Biotechnology, 44, 16-26. https://doi.org/10.1016/j.copbio.2016.10.004

[13] Lyons, G. (2018) Biofortification of Cereals with Foliar Selenium and Iodine Could Reduce Hypothyroidism. Frontiers in Plant Science, 9, 730. https://doi.org/10.3389/fpls.2018.00730

[14] Philip, J.W. and Martin, R.B. (2009) Biofortification of Crops with Seven Mineral Elements Often Lacking in Human Diets-Iron, Zinc, Copper, Calcium, Magnesium, Selenium and Iodine. New Phytologist, 182, 49-84. https://doi.org/10.1111/j.1469-8137.2008.02738.x

[15] Ujowundu, C.O., Ukoha, A.I., Agha, N.C., Nwachukwu, N. and Igwe, K.O. (2009) Iodine Biofortification of Selected Plants Using Potassium Iodide. Nigerian Journal of Biochemistry and Molecular Biology, 24, 17-21.

[16] Landini, M., Gonzali, S. and Perata, P. (2011) Iodine Biofortification in Tomato. Journal of Plant Nutrition and Soil Science, 174, 480-486. https://doi.org/10.1002/jpln.201000395

[17] Prasad, B.V.G., Mohanta, S., Rahaman, S. and Prerna, B. (2015) Bio-Fortification in Horticultural Crops. Journal of Agricultural Engineering and Food Technology, 2, 95-99.

[18] Rosell, C.M. (2016) Fortification of Grain-Based Foods. Reference Module in Food Science. Elsevier, Amsterdam. https://doi.org/10.1016/B978-0-08-100596-5.00074-3

[19] Montalvo, D., Degryse, F., da Silva, R.C., Baird, R. and McLaughlin, M.J. (2016) Chapter Five-Agronomic Effectiveness of Zinc Sources as Micronutrient Fertilizer. Advances in Agronomy, 139, 215-267. https://doi.org/10.1016/bs.agron.2016.05.004

[20] Penelope, N., Howarth, E.B., Meenakshi, J.V. and Wolfgang, P. (2006) Symposium: Food Fortification in Developing Countries Biofortification of Staple Food Crops. American Society for Nutrition, Rockville, 1064-1067. https://doi.org/10.1093/jn/136.4.1064

[21] Amy, S., Meike, S.A., et al. (2016) Biofortification Techniques to Improve Food Security. Reference Module in Food Science. Elsevier, Amsterdam. https://doi.org/10.1016/B978-0-08-100596-5.03078-X

[22] Taylor, J.R.N. and Duodu, K.G. (2017) Sorghum and Millets: Grain-Quality Characteristics and Management of Quality Requirements. In: Wrigley, C., Batey, I. and Miskelly, D., Eds., Cereal Grains. Assessing and Managing Quality Woodhead Publishing Series in Food Science, Technology and Nutrition, 2nd Edition, Elsevier, 
Amsterdam, Chapter 13, 317-351.

https://doi.org/10.1016/B978-0-08-100719-8.00013-9

[23] Howarth, E.B. and Amy, S. (2017) Improving Nutrition through Biofortification: A Review of Evidence from HarvestPlus, 2003 through 2016. Global Food Security, 12, 49-58. https://doi.org/10.1016/j.gfs.2017.01.009

[24] Anarado, C.E., Anarado, C.J.O., Okeke, M.O., Ezeh, C.E., Umedum, N.L. and Okafor, P.C. (2019) Leafy Vegetables as Potential Pathways to Heavy Metal Hazards. Journal of Agricultural Chemistry and Environment, 8, 23-32. https://doi.org/10.4236/jacen.2019.81003

[25] Prasan, R.B. (2012) Curry Leaf (Murraya koenigii) or Cure Leaf: Review of Its Curative Properties. Journal of Medical Nutrition and Nutraceuticals, 1, 92-97. https://doi.org/10.4103/2278-019X.101295

[26] Iwu, M.M. (1993) Handbook of African Medicinal Plants. URP Press, Bocarolon, 229.

[27] Vera, K.M., Senka, M.P., Zuzana, P., Ljiljana, R. and Draginja, P. (2011) Phenolic Acids in Pumpkin (Cucurbita pepo L.) Seeds. In: Preedy, V.R., Watson, R.R. and Patel, V.B., Eds., Nuts and Seeds in Health and Disease Prevention, Elsevier, Amsterdam, 925-932. https://doi.org/10.1016/B978-0-12-375688-6.10109-4

[28] Mohamed Saleem, T.S., Madhusudhana Chetty, C., Ramkanth, S., Alagusundaram, M., Gnanaprakash, K., Thiruvengada Rajan, V.S. and Angalaparameswari, S. (2009) Solanum nigrum Linn.-A Review. Pharmacognosy Review, 3, 342-345.

[29] Akubugwo, I.E., Obasi, N.L., Chinyere, G.C. and Ugbogu, A.E. (2007) Nutritional and Chemical Value of Amaranthus hybridus L. Leaves from Afikpo, Nigeria. African Journal of Biotechnology, 6, 2833-2839. https://doi.org/10.5897/AJB2007.000-2452

[30] Priya, S., Varun, C., Brahm, K.T., Shubhendra, S.C., Sobita, S., Bilal, S. and Abidi, A.B. (2014) N Overview on Okra (Abelmoschus esculentus) and It's Importance as a Nutritive Vegetable in the World. International Journal of Pharmacy and Biological Sciences, 4, 227-233.

[31] Habib, O.A., Léonard, E.A., et al. (2018) Ethnobotanical Knowledge of Jute (Corchorus olitorius L.) in Benin. European Journal of Medicinal Plants, 26, 1-11. https://doi.org/10.9734/EJMP/2018/43897

[32] Trivedi, M., Singh, R., Shukla, M. and Tiwari, R.K. (2016) GMO and Food Security. In: Omkar, Ed., Ecofriendly Pest Management for Food Security, Elsevier, Amsterdam, 703-726. https://doi.org/10.1016/B978-0-12-803265-7.00023-3

[33] Mbaveng, A.T. and Kuete, V. (2017) Zingiber officinale. In: Medicinal Spices and Vegetables from Africa, Elsevier, Amsterdam, 637-639. https://doi.org/10.1016/B978-0-12-809286-6.00030-3

[34] Ajayi, S.A., Berjak, P., Kioko, J.I., Dulloo, M.E. and Vodouhe, R.S. (2006) Responses of Fluted Pumpkin (Telfairia occidentalis Hook. f.; Cucurbitaceae) Seeds to Desiccation, Chilling and Hydrated Storage. South African Journal of Botany, 72, 544-550. https://doi.org/10.1016/j.sajb.2006.02.001

[35] Okoli, B.E. and Mgbeogu, C.M. (1983) Fluted Pumpkin, Telfairia occidentalis. West African Vegetable Crop. Economic Botany, 32, 145-149. https://doi.org/10.1007/BF02858775

[36] Aja, P.M., Okaka, A.N.C., Onu, P.N., Ibiam, U. and Urako, A.J. (2010) Phytochemical Composition of Talinum triangulare (Water Leaf) Leaves. Pakistan Journal of Nutrition, 9, 527-530. https://doi.org/10.3923/pjn.2010.527.530 
[37] Knapp, S., Vorontsova, M.S. and Prohens, J. (2013) Wild Relatives of the Eggplant (Solanum melongena L.): Solanaceae, New Understanding of Species Names in a Complex Group. PLOS ONE, 8, e57039. https://doi.org/10.1371/journal.pone.0057039

[38] Hirakawa, H., Shirasawa, K., Miyatake, K., et al. (2014) Draft Genome Sequence of Eggplant (Solanum melongena L.): The Representative Solanum Species Indigenous to the Old World. DNA Research, 21, 649-660. https://doi.org/10.1093/dnares/dsu027

[39] Ranganathan, S. (1995) Iodised Salt Is Safe. Indian Journal of Public Health, 39, 164-171.

[40] Shetty, A., Rao, C.R., Kamath, A., Sp, V. and Reddy, T.S.K. (2019) Goiter Prevalence and Interrelated Components from Coastal Karnataka. The Indian Journal of Pediatrics, 86, 159-164. https://doi.org/10.1007/s12098-018-2757-2

[41] Yadav, S., Gupta, S.K., Godbole, M.M., Jain, M., Singh, U., Pavithran, V.P., Boddula, R., Mishra, A., Shrivastava, A., Tandon, A., Ora, M., Chowhan, A., Shukla, M., Yadav, N., Babu, S., Dubey, M. and Awasthi, P.K. (2010) Persistence of Severe Iodine-Deficiency Disorders Despite Universal Salt Iodization in an Iodine-Deficient Area in Northern India. Public Health Nutrition, 13, 424-429. https://doi.org/10.1017/S1368980009990280

[42] Dat, T.Q., Giang, L.N.H., Bao, P.V. and Tuyen, N.T.H. (2019) Prevalence of Goiter among Children Aged 8-10 in Binh Dinh Province, Vietnam in 2016-2017. AIMS Public Health, 6, 184-194. https://doi.org/10.3934/publichealth.2019.2.184

[43] Delshad, H. and Azizi, F. (2017) Review of Iodine Nutrition in Iranian Population in the Past Quarter of Century. International Journal of Endocrinology and Metabolism, 15, e57758. https://doi.org/10.5812/ijem.57758

[44] Yusuf, H.K., Rahman, A.M., Chowdhury, F.P., Mohiduzzaman, M., Banu, C.P., Sattar, M.A. and Islam, M.N. (2008) Iodine Deficiency Disorders in Bangladesh, 2004-05: Ten Years of Iodized Salt Intervention Brings Remarkable Achievement in Lowering Goitre and Iodine Deficiency among Children and Women. Asia Pacific Journal of Clinical Nutrition, 17, 620-628.

[45] Heydon, E.E., Thomson, C.D., Mann, J., Williams, S.M., Skeaff, S.A., Sherpa, K.T. and Heydon, J.L. (2009) Iodine Status in a Sherpa Community in a Village of the Khumbu Region of Nepal. Public Health Nutrition, 12, 1431-1436. https://doi.org/10.1017/S1368980008004242

[46] De Benoist, B. and Delange, F. (2002) Iodine Deficiency: Current Situation and Future Prospects. Sante, 12, 9-17.

[47] Nyenwe, E.A. and Dagogo-Jack, S. (2009) Iodine Deficiency Disorders in the Iodine-Replete Environment. The American Journal of the Medical Sciences, 337, 37-40. https://doi.org/10.1097/MAJ.0b013e31817baaf0

[48] Pearce, E.N., Andersson, M. and Zimmermann, M.B. (2013) Global Iodine Nutrition: Where Do We Stand in 2013? Thyroid, 23, 523-528.

https://doi.org/10.1089/thy.2013.0128

[49] Rossi, L. and Branca, F. (2003) Salt Iodisation and Public Health Campaigns to Eradicate Iodine Deficiency Disorders in Armenia. Public Health Nutrition, 6, 463-469. https://doi.org/10.1079/PHN2003461

[50] Saha, S., Abu, B.A.Z., Jamshidi-Naeini, Y., Mukherjee, U., Miller, M., Peng, L.L. and Oldewage-Theron, W. (2019) Is Iodine Deficiency Still a Problem in Sub-Saharan Africa? A Review. Proceedings of the Nutrition Society, 11, 1-13. 
https://doi.org/10.1017/S0029665118002859

[51] Izzeldin, S.H., Crawford, M.A. and Ghebremeskel, K. (2009) Salt Fortification with Iodine: Sudan Situation Analysis. Nutrition and Health, 20, 21-30. https://doi.org/10.1177/026010600902000103

[52] Chuot, C.C., Galukande, M., Ibingira, C., Kisa, N. and Fualal, J.O. (2014) Iodine Deficiency among Goiter Patients in Rural South Sudan. BMC Research Notes, 7, 751. https://doi.org/10.1186/1756-0500-7-751

[53] Mezgebu, Y., Mossie, A., Rajesh, P. and Beyene, G. (2012) Prevalence and Severity of Iodine Deficiency Disorder among Children 6-12 Years of Age in Shebe Senbo District, Jimma Zone, Southwest Ethiopia. Ethiopian Journal of Health Sciences, 22, 196-204.

[54] Fereja, M., Gebremedhin, S., Gebreegziabher, T., Girma, M. and Stoecker, B.J. (2018) Prevalence of Iodine Deficiency and Associated Factors among Pregnant Women in Ada District, Oromia Region, Ethiopia: A Cross-Sectional Study. BMC Pregnancy Childbirth, 18, 257. https://doi.org/10.1186/s12884-018-1905-Z

[55] Harika, R., Faber, M., Samuel, F., Kimiywe, J., Mulugeta, A. and Eilander, A.(2017) Micronutrient Status and Dietary Intake of Iron, Vitamin A, Iodine, Folate and Zinc in Women of Reproductive Age and Pregnant Women in Ethiopia, Kenya, Nigeria and South Africa: A Systematic Review of Data from 2005 to 2015. Nutrients, 9, pii: E1096. https://doi.org/10.3390/nu9101096

[56] Ogbera, A.O. and Kuku, S.F. (2011) Epidemiology of Thyroid Diseases in Africa. Indian Journal of Endocrinology and Metabolism, 15, 82-88. https://doi.org/10.4103/2230-8210.83331

[57] Mshelia, D.S., Bakari, A.A., Mubi, B.M., Ali, N., Musa, A.H., Gali, R.M. and Mamza, Y.P. (2016) Biochemical Pattern of Thyroid Disorders in Maiduguri, Northeastern Nigeria. World Journal of Medicine and medical Science Research, 4, 32-38.

[58] Ogbera, A.O., Fasanmade, O. and Adediran, O. (2007) Pattern of Thyroid Disorders in the Southwestern Region of Nigeria. Ethnicity \& Disease, 17, 327-330.

[59] Salami, B.A., Odusan, O., Ebili, H.O. and Akintola, P.A. (2016) Spectrum and Prevalence of Thyroid Diseases Seen at a Tertiary Health Facility in Sagamu, South-West Nigeria. Nigerian Postgraduate Medical Journal, 23, 137-140. https://doi.org/10.4103/1117-1936.190345 http://www.npmj.org/text.asp?2016/23/3/137/190345

[60] Sarmugam, R. and Worsley, A. (2014) Current Levels of Salt Knowledge: A Review of the Literature. Nutrients, 6, 5534-5559. https://doi.org/10.3390/nu6125534 